\title{
MUCOPOLYSACCHARIDES IN SYNOVIAL FLUID DETECTION OF CHONDROITIN SULPHATE
}

\author{
BY
}

\author{
S. A. BARKER, C. F. HAWKINS, AND M. HEWINS
}

From the Department of Chemistry, University of Birmingham, and the Queen Elizabeth Hospital, Birmingham

Hyaluronic acid is usually the only polysaccharide present in human synovial fluid. However, the finding of abnormally high amounts of galactosamine suggested that other polysaccharides, perhaps originating from ground substance, might also occur (Laurent, 1957; Smith, Crowley, and Giles, 1960). Their presence has hitherto been only surmised, for galactosamine could have arisen from the carbohydrate moiety of mucoproteins and not from chondroitin sulphate itself; but we did detect a sulphated mucopolysaccharide in synovial fluid obtained from a patient with osteo-arthritis, the only instance among nineteen patients with various forms of arthritis (Barker, Bayyuk, Brimacombe, Hawkins, and Stacey, 1963). We now report a study in which a particular search has been made for such polysaccharides. At the same time, techniques for separating synovial hyaluronic acid and for isolating the hyaluronic acid-protein complexes have been examined further.
Material and Methods
Material
Synovial fluid was aspirated from the knee joints of twelve patients, of whom the clinical details are listed ino the Table. Diagnosis of rheumatoid arthritis, made by one of us (C.F.H.), was established according to the $\frac{}{Z}$ criteria set forth by the American Rheumatism Associa-》 tion (Ropes, Bennett, Cobb, Jacox, and Jessar, 1957). We accepted as normal fluid obtained from apparentlye normal joints during the operation for meniscectomy. Fluids were stored in sterile bottles at $-25^{\circ} \mathrm{C}$.

\section{Methods}

(1) Separation of Hyaluronic Acid-Protein Complexeso from Free Proteins by Fractionation of Synovial Fluid on气 Diethylaminoethyl (DEAE) Sephadex.-The gel filtration̊ media, Sephadex, is synthesized by cross-linking the poly $-\vec{\overrightarrow{ }}$ saccharide, dextran, to give a three-dimensional network. $\frac{3}{3}$ A swollen Sephadex gel excludes molecules which exceed a certain size, smaller molecules penetrating the gel to an extent dependent upon their size. A mixture of macromolecules is eluted from the gel in order of decreasing

TABLE

CLINICAL PARTICULARS OF TWELVE PATIENTS

\begin{tabular}{|c|c|c|c|c|c|c|}
\hline $\begin{array}{l}\text { Case } \\
\text { No. }\end{array}$ & Sex & $\begin{array}{c}\text { Age } \\
\text { (yrs) }\end{array}$ & Diagnosis & $\begin{array}{l}\text { Waaler-Rose } \\
\text { Test }\end{array}$ & $\begin{array}{c}\text { Erythrocyte } \\
\text { Sedimentation } \\
\text { Rate } \\
\text { (mm./1 hr } \\
\text { Westergren) }\end{array}$ & $\underset{(\mathrm{g} . / 100 \mathrm{ml} .)}{\mathrm{Hb}}$ \\
\hline 1 & $\mathbf{M}$ & 30 & Traumatic synovitis & - & - & 一 \\
\hline 2 & $\mathbf{M}$ & 35 & Traumatic synovitis & - & - & - \\
\hline $\begin{array}{l}3 \\
4 \\
5 \\
6 \\
7 \\
8 \\
9\end{array}$ & $\begin{array}{l}\mathbf{M} \\
\mathbf{F} \\
\mathbf{M} \\
\mathbf{F} \\
\mathbf{F} \\
\mathbf{M} \\
\mathbf{M}\end{array}$ & $\begin{array}{l}60 \\
60 \\
58 \\
55 \\
58 \\
65\end{array}$ & $\begin{array}{l}\text { Rheumatoid arthritis (definite) } \\
\text { Rheumatoid arthritis (definite) } \\
\text { Rheumatoid arthritis (classical) } \\
\text { Rheumatoid arthritis (classical) } \\
\text { Rheumatoid arthritis (classical) } \\
\text { Osteo-arthritis } \\
\text { Osteo-arthritis of knees }\end{array}$ & $\begin{array}{l}\text { Negative } \\
\text { Negative } \\
1 / 1,024 \\
\text { Negative } \\
1 / 1,024 \\
\text { Negative } \\
1 / 32\end{array}$ & $\begin{array}{r}11 \\
38 \\
20 \\
9 \\
44 \\
74\end{array}$ & $\begin{array}{l}14 \cdot 6 \\
11 \cdot 1 \\
12 \cdot 3 \\
11 \cdot 7 \\
11 \\
12 \cdot 9\end{array}$ \\
\hline 10 & $\mathbf{F}$ & 61 & $\begin{array}{l}\text { Rheumatoid arthritis (classical) } \\
\text { Osteo-arthritis of knees }\end{array}$ & & 32 & $12 \cdot 3$ \\
\hline 11 & $\mathbf{F}$ & $\begin{array}{l}60 \\
67\end{array}$ & $\begin{array}{l}\text { Rheumatoid arthritis (definite) } \\
\text { Rheumatoid arthritis (classical) } \\
\text { Rheumatoid arthritis (classical) }\end{array}$ & $\begin{array}{l}1 / 128 \\
1 / 128\end{array}$ & $\begin{array}{r}115 \\
48\end{array}$ & $\begin{array}{l}10 \cdot 8 \\
12 \cdot 9\end{array}$ \\
\hline
\end{tabular}


molecular weight. Chemical attachment of diethylaminoethyl (DEAE) residues to Sephadex produces a high capacity anion exchanger with low non-specific adsorption.

Aliquots (3 to $6 \mathrm{ml}$.) of each fluid were diluted with buffer and passed down columns of DEAE-Sephadex $(30 \times 2.8 \mathrm{~cm}$.), equilibrated with $0 \cdot 1 \mathrm{M}$-phosphate buffer, $\mathrm{pH} 7$, and eluted $(500 \mathrm{ml}$.) with a linear gradient $(0.02 \rightarrow$ $0.7 \mathrm{M})$ of $\mathrm{NaCl}$ in the same buffer. Thereafter the column was washed with $2 \mathrm{M} \mathrm{NaCl}$ in phosphate buffer $(25 \mathrm{ml}$.) followed by a linear gradient $(0 \cdot 2 \mathrm{M} \rightarrow 2 \mathrm{M})$ of $\mathrm{NaCl}$ hydrochloric acid $(100 \mathrm{ml}$.) in equimolar proportions. The fractions $(5 \mathrm{ml}$.) were scanned for proteins using the optical density at $279 \mathrm{~m} \mu$, and for hexuronic acid by a modification (Gregory, 1960) of the Dische (1947) carbazole reaction. A reference curve was prepared, using D - glucurone as the standard.

(2) Fractionation of Deproteinized Synovial Fluid by Sephadex Gel-200 to isolate Mucopolysaccharide Fractions.-Pronase $\mathrm{P}(5 \mathrm{mg}$.) in $0 \cdot 1 \mathrm{M}$ phosphate buffer, pH7 (5 ml.), containing a trace of calcium chloride was sterilized by passage through a Hemming filter and incubated at $37^{\circ} \mathrm{C}$. for 24 hours with synovial fluid ( 3 to $6 \mathrm{ml}$.) in the dialysis bag of a sterile, aseptic dialysis apparatus (Chelton and James, 1963) containing the same buffer in its outer compartment. The digest was fractionated on a column $(30 \times 2.8 \mathrm{~cm}$.) of Sephadex gel200 , equilibrated with $0 \cdot 1 \mathrm{M}$ - phosphate buffer, $p \mathrm{H} 7$, and eluted with the same buffer at 7 to $10 \mathrm{ml}$. per hour. The fractions $(5 \mathrm{ml}$.) were assayed for peptide debris, using the ninhydrin assay of Moore and Stein (1948), and for uronic acid (Gregory, 1960).

(3) Other Studies of the Mucopolysaccharide Fractions (a) Protein content was assayed by the method of Lowry, Rosebrough, Farr, and Randall (1951) calibrated against serum albumin.

(b) The ester sulphate content was determined by the method of Jones and Letham (1956).

(c) Where desirable the mucopolysaccharide was further fractionated on a calibrated column of Deacidite FF (Chloride form) as described by Barker, Cruickshank, and Webb (1965). This procedure separates protein debris, hyaluronic acid, chondroitin 4- and 6- sulphates, dermatan sulphate, heparin, and keratan sulphate. Column eluates were scanned with orcinol (Svennerholm, 1956).

\section{Results}

Fractionation on DEAE-Sephadex and elution with a solution of $\mathrm{NaCl}(-0 \cdot 32 \mathrm{M})$ separated free protein from protein-polysaccharide complexes in synovial fluids from twelve patients.

"Normal" fluid, obtained during operation for meniscectomy, was unique in showing a protein peak at $0.0 \mathrm{M} \mathrm{NaCl}$, together with one at $0.04 \mathrm{M} \mathrm{NaCl}$ and the hyaluronic acid-protein complexes were eluted in a series of peaks between 0.27 and $0.55 \mathrm{M}$
$-\mathrm{NaCl}$ (Fig. 1, opposite lower diagram). Fluids from Patients 1 and 2 with traumatic synovitis showed a remarkable similarity in the elution pattern (Fig. 1, upper diagrams) of their hyaluronic acid-protein complexes, namely a multiplicity of peaks above $0.48 \mathrm{M} \mathrm{NaCl}$, some requiring acidic elution. Further examination of the polysaccharide-protein complexes of one of these fluids revealed the presence of hexosamine and hexuronic acid, though there was no combined sulphate; the protein contents were $23,22 \cdot 9,20 \cdot 4$, and 49 per cent. respectively, in order of elution.

Fluids from three cases of rheumatoid arthritis (Nos 3, 4, and 5) also showed only complexes of the hyaluronic acid-protein type, eluted at about $0 \cdot 3 \mathrm{M}$ $\mathrm{NaCl}$, which sometimes required acidic elution. The protein contents of mucopolysaccharide fractions from two of them were $31 \cdot 5,12,8,9 \cdot 7,13 \cdot 2$, and $7 \cdot 7$ per cent. for No. 3 and $35,5 \cdot 7,9 \cdot 6$, and $23 \cdot 8$ per cent. for No. 4, in order of elution. Two other cases of rheumatoid arthritis (Nos 6 and 7), in whom the disease was complicated by peripheral neuropathy, had synovial fluid of particular interest for both contained only traces of hyaluronic acid eluted in the range $0.32-0.45 \mathrm{M} \mathrm{NaCl}$. In No. 6 the remaining mucopolysaccharide complexes were sulphated (12 and $14 \cdot 5$ per cent. sulphate) and eluted only in the acid range, and persisted following treatment with intra-articular prednisolone. However, after 3 days' treatment, the polysaccharide (0sulphate 14 per cent.) was eluted at $0.42-0.5 \mathrm{M}$ $\mathrm{NaCl}$, and after 7 days' treatment it was eluted in two fractions ( 0 -sulphate 12 and 13 per cent. respectively) in the range $0.43-0.51 \mathrm{M} \mathrm{NaCl}$ and $0.51-0.55 \mathrm{M}$ $\mathrm{NaCl}$.

No such sulphated polysaccharide was found in a patient with osteo-arthritis (No. 8) or in one with osteo-arthritis and rheumatoid arthritis (No. 9). In No. 8 protein contents of the mucopolysaccharide fractions were $10 \cdot 8,24 \cdot 8$, and $19 \cdot 6$ per cent. respectively, in order of elution.

In order to examine more closely those cases in which infiltration of sulphated mucopolysaccharides into synovial fluid had occurred, a series of fluids were deproteinized with Pronase under aseptic conditions. It was then possible to separate the polysaccharide component from the protein debris by fractionation on Sephadex gel-200, only the polysaccharide being excluded from the gel. The nature of the polysaccharide present was ascertained by passage down a calibrated column of Deacidite FF (Chloride form). Extensive investigation of separations of human cartilage (Barker, Guy, and Cruickshank, 1965) and skin constituents (Barker, 


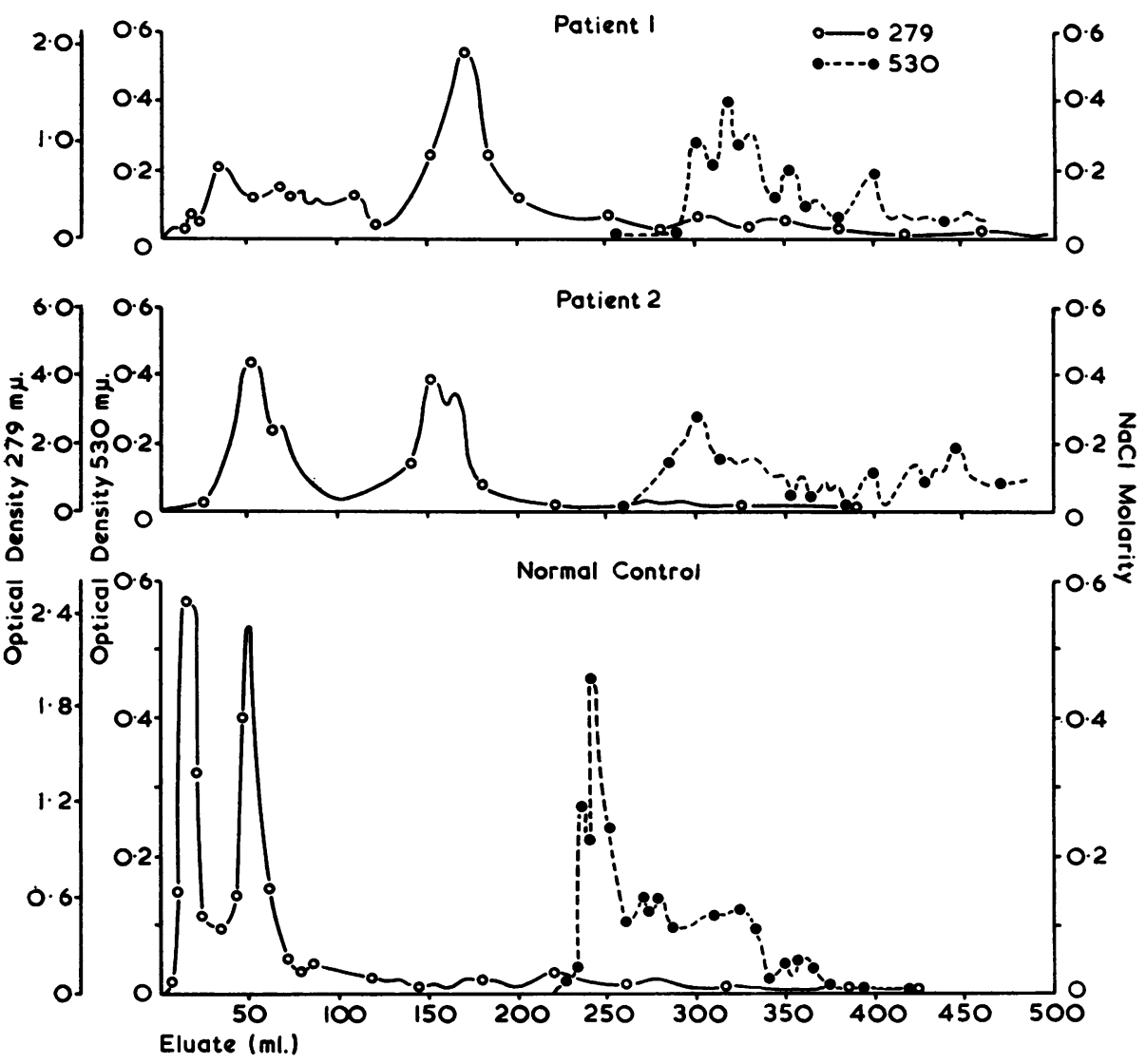

Fig. 1.-Fractionatioro of the synovial fluids of two patients with traug matic synovitis on DEAE-Sephadex. Lowe arge diagram is that of 2 control normal fluid obo tained at meniscectomy

Cruickshank, and Webb, 1965) has established the reproducibility of the point of elution of a particular polysaccharide of the ground substance, so that the method can now be used with some confidence to establish the constituents of mixtures. Examined in this way the fluid of patient No. 10, who had rheumatoid arthritis and osteo-arthritis of the knees, showed only protein debris and the single peak of hyaluronic acid with no other polysaccharides of ground substance present. Sulphated mucopoly: saccharides were also encountered in the synoviaf5 fluid (Fig. 2) of patient No. 11, who had rheumatoidb arthritis.

Another sample of fluid from patient No. 12, who had rheumatoid arthritis complicated by periphera $\mathrm{B}$ neuropathy, showed unique changes. When theo

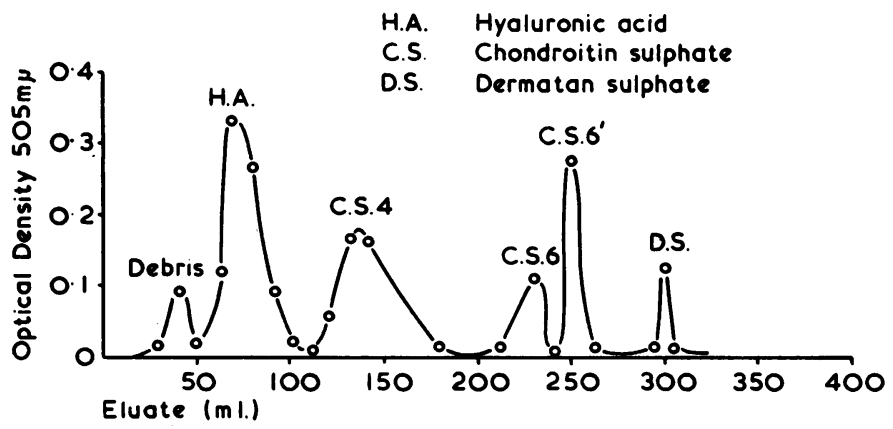

Fig. 2-Fluid from patient with rheumatoiø arthritis showing evidence of ground sub stance of ground sub stance infiltration. 
deproteinized fluid was fractionated on Sephadex gel-200, some polysaccharide was excluded (eluent volume 70 to $140 \mathrm{ml}$.) by the gel and the rest included (140 to $200 \mathrm{ml}$.) accompanied by protein debris. This latter feature was not seen in twenty other pathological fluids examined. The two polysaccharide fractions were separately fractionated on columns of Deacidite FF (Fig. 3). The main constituents of the included fraction were hyaluronic acid and chondroitin 6-sulphate, the latter probably present as the normal and oversulphated analogues found by Barker, Guy, and Cruickshank (1965) in human knee cartilage. Keratan sulphate was concentrated in the included fraction while chondroitin 4-sulphate was concentrated in the excluded polysaccharide.

\section{Discussion}

Mucopolysaccharides, such as chondroitin sulphate, may occasionally be detected in the synovial fluid of patients with arthritis. These have probably infiltrated into synovial fluid from the ground substance of cartilage, in contrast to hyaluronic acid, which is produced by synovial cells. The fact that chondroitin sulphate was found more commonly in rheumatoid synovial fluid was probably due to the selection of our clinical material and we have found it also in osteo-arthritic synovial fluid. Three samples of fluid from patients with rheumatoid arthritis (Nos 6, 7, and 12) were of particular interest, as they showed an unusual pattern of depolymerized hyaluronic acid and Nos 6 and 12 showed sulphated mucopolysaccharides. It was of interest that in all three patients the arthritis was complicated by peripheral neuropathy. The possibility that loss of sensation might cause greater damage to the joint from loss of protective reflexes, as in Charcot's joints, and so cause liberation of mucopolysaccharides from damaged cartilage was considered unlikely; and, in one bed-ridden patient, sensation in the knees was normal. Peripheral neuropathy usually occurs in severe cases of rheumatoid disease, so severity alone might explain it; also it is generally a manifestation of arteritis, so that damage from ischaemia of vessels supplying joint surfaces and synovial tissues may have caused liberation of enzymes which depolymerize hyaluronic acid, and may have released ground substance from cartilage, but there is no means of confirming this hypothesis. Alternatively, the neuropathy may have been coincidental. The clinical and radiological examination of the joints revealed nothing which explained this occasional finding of mucopolysaccharides.

\section{Summary}

Mucopolysaccharides, originating from ground substance, have been isolated from synovial fluid from three patients with rheumatoid arthritis. Mucopolysaccharide-protein complexes, including chondroitin sulphate, have been studied after separation of free proteins by DEAE-Sephadex and after passage of the deproteinized fluid down Sephadex gel-200.

The authors are indebted to the Nuffield Rheumatism Research Council for financial support.

\section{REFERENCES}

Barker, S. A., Bayyuk, S. H. I., Brimacombe, J. S., Hawkins, C. F., and Stacey, M. (1963). Clin. chim. Acta, 8, 902.

—, Cruickshank, C. N. D., and Webb, T. P. (1965). Carbohydrate Res., 1, 52.

-, Guy, R. C. E., and Cruickshank, C. N. D. (1965). Ibid., 1, 312.

Chelton, E. T. J., and James, C. G. (1963). Chem. and Industry (Lond.), 1077.

Dische, Z. (1947). J. biol. Chem., 167, 189.

Gregory, J. D. (1960). Arch. Biochem. Biophys. Acta, 89, 157.

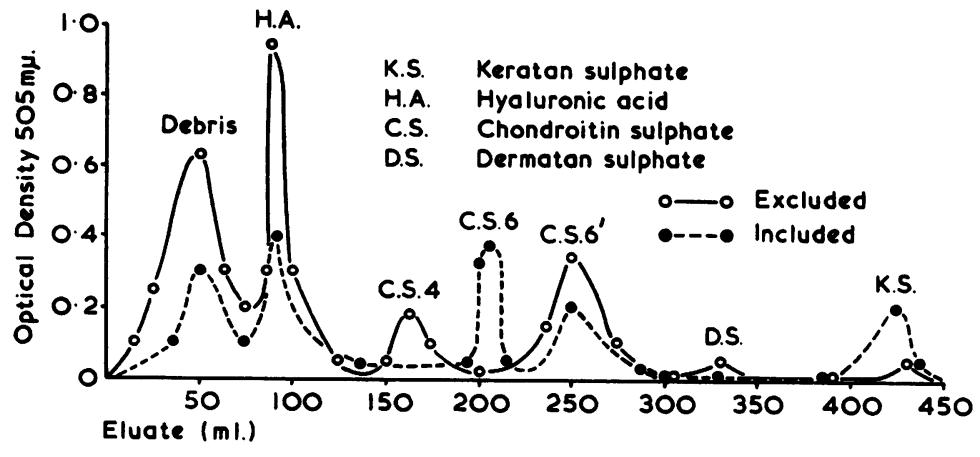

Fig. 3.-Fractionation of mucopolysaccharides from a deproteinized synovial fluid exclued and included on a
Sephadex gel-200 column. 
Jones, A. S., and Letham, D. S. (1956). Analyst, 81, 15.

Laurent, T. C. (1957). Arkiv. für Kemi., 11, 487.

Lowry, O. H., Rosebrough, N. J., Farr, A. L., and Randall, R. J. (1951). J. biol. Chem., 193, 265.

Moore, S., and Stein, W. H. (1948). Ibid., 176, 367.

Ropes, M. W., Bennett, G. A., Cobb, S., Jacox, R., and Jessar, R. A. (1959). Ann. rheum. Dis., 18, 49.

Smith, J. E., Crowley, G. T., and Giles, R. B. (1960). Arthr. and Rheum., 3, 409.

Svennerholm, L. (1956). J. Neurochem., 1, 42.

Les mucopolysaccharides dans le liquide synovial La détection du sulfate de chondroïtine

RÉSUMÉ

Des mucopolysaccharides, provenant de la matrice, ont été isolés_du.liquide synovial de trois malades atteints d'arthrite rhumatismale. Des complexes mucopolysaccharide-protéine, y compris le sulfate de chondroïtine, 드. ont été étudiés après la séparation des protéines libres pare DEAE-Sephadex et après le passage du liquide depro- $\Rightarrow$ téinisé par Sephadex gel-200.

\section{Los mucopolisacaridos en el líquido sinovial} El aislamiento del sulfato de condroitina

\section{SUMARIO}

Mucopolisacaridos, procedentes de la matriz, fueron $\vec{\odot}$ aislados del líquido sinovial de tres enfermos con artritis reumatoide. Complejos mucopolisacarido-proteina, incluso con el sulfato de condroitina, fueron estudiados después de la separación de las proteinas libres por DEAE-Sephadex y después de pasar el líquido depro teinizado por Sephadex gel-200. 